\title{
PERAN BRAND AMBASSADOR TERHADAP MINAT BELI MELALUI BRAND AWARENESS
}

\author{
Agi Rosyadi \\ Universitas Siliwangi \\ Email: agirosyadi@unsil.ac.id
}

\begin{abstract}
The importance of brand awareness on android smartphone products can certainly boost consumer buying interest especially through brand ambassadors who will be able to communicate the values of the brand or product effectively to the target market, the strength of the brand ambassador is thought to have an influence that can increase trust. The purpose of this study was to see the influence of brand ambassadors on purchase intention through brand awareness. The survey was conducted on 110 Android smartphone users who have just made purchases for less than 1 year. The analytical tool used in this research is SEM analysis with brand ambassador as the independent variable, brand awareness and purchase intention as the dependent variable. The results of this study indicate that brand ambassadors have a direct effect on brand awareness and purchase interest, and brand awareness has an effect on purchase intention. Therefore, the better the brand ambassador strategy which includes visibility, credibility, attraction, and power will increase awareness which has an impact on increasing consumer buying interest in Android smartphones in Tasikmalaya.
\end{abstract}

Keywords: brand ambassador, purchase intention, brand awareness.

\begin{abstract}
ABSTRAK
Pentingnya kesadaran merek pada produk smartphone android tentunya dapat mendongkrak minat beli konsumen terlebih melalui brand ambassador akan mampu mengkomunikasikan nilai-nilai merek atau produk tersebut secara efektif kepada target pasar, kekuatan brand ambassador diduga dapat memberikan pengaruh yang mampu meningkatkan kepercayaan. Tujuan penelitian ini adalah untuk melihat pengaruh brand ambassador terhadap minat beli melalui brand awareness. Metode penelitian menggunakan pendekatan kuantitatif melalui survey dilakukan kepada 110 pengguna smartphone Android yang baru melakukan pembelian kurang dari 1 tahun. Alat analisis yang digunakan dalam penelitian ini adalah analisis SEM dengan brand ambassador sebagai variabel bebas, brand awareness dan minat beli sebagai variabel terikat. Hasil penelitian ini menunjukkan bahwa brand ambassador berpengaruh langsung terhadap brand awareness dan minat beli, dan brand awareness berpengaruh terhadap minat beli. Oleh karena itu, semakin baik strategi brand ambassador yang meliputi visibility, credibility, attraction, dan power akan meningkatkan awarenees yang berdampak pada peningkatan minat beli konsumen smartphone android di Tasikmalaya.
\end{abstract}

Kata Kunci: brand ambassador, minat beli, brand awareness. 


\section{PENDAHULUAN}

\section{Latar Belakang}

Kondisi ekonomi pada zaman sekarang yang sudah begitu modern, mengharuskan para pelaku ekonomi untuk semakin lebih kreatif dalam menjalankan usahanya agar bisa bertahan di tengah persaingan yang begitu ketat. Para pelaku usaha menggunakan cara yang beraneka ragam dengan harapan dapat mengembangkan usahanya menjadi lebih besar dan nantinya dapat menjadi pemimpin pasar. Salah satu lini usaha yang begitu menjamur pada saat ini adalah munculnya berbagai macam jenis perangkat seluler yang semakin hari semakin banyak jenis, bentuk dan modelnya.

Tercatat ada beberapa jenis merek yang termasuk cukup digandrungi oleh masyarakat Indonesia, sebut saja dari merek Samsung, Apple, Oppo, Xiaomi, Vivo, Huawei dan masih banyak lagi merek yang lain. Semuanya menawarkan fitur yang bermacam-macam yang tentunya jika fiturnya semakin banyak dan canggih maka akan berdampak terhadap harganya yang semakin mahal. Berbagai cara dilakukan, agar produk yang sudah diproduksi dapat diterima oleh pasar.

Pasar menanggapinya dengan begitu terbuka, jelas ini menjadi peluang bagi para vendor untuk dapat bergabung di tengah ketatnya persaingan telepon seluler. Hal ini dapat terlihat dari banyaknya promosi yang dilakukan oleh sejumlah vendor terhadap produk yang mereka lempar ke pasaran. Promosinya sangat beragam, ada yang menggunakan diskon, ada yang menggunakan strategi harga yang murah tapi fitur berlimpah, serta ada pula yang menggunakan sejumlah artis sebagai brand ambassador produknya.

Salah satu contoh vendor yang menggunakan jasa artis sebagai brand ambassador-nya yaitu Vivo. Untuk pertama kalinya Vivo memasuki pasar global Asia Tenggara dan India sekitar tahun 2014 dan semakin meningkat namanya sebagai produk yang relatif premium di China yang menjadi salah satu produk dengan penjualan terbaik dan produk unggulannya yaitu Xplay5 dengan produk termahal yaitu dengan tarif sekitar USD 600. Di Indonesia sendiri Vivo mengalami pertumbuhan yang sangat baik. Bagaimana tidak, perusahaan Vivo terus berinovasi dalam menggalakan rangkaian produk yang sesuai dengan kebutuhan dan keinginan pasar smartphone di Indonesia. Usaha tersebut juga ditunjang dengan promosi yang massive dengan menggunakan Agnes Monica sebagai brand ambassador Vivo. Siapa yang tidak mengenal Agnes Monica apalagi kaum milenial yang sekarang sedang menjadi "pasar empuk" bagi para pelaku usaha telepon seluler. Pengunaan brand ambasador juga banyak digunakan merek smartphone lain di Indonesia seperti Samsung, Asus, Oppo dan lainnya.

International Data Corporation (IDC) menyatakan bahwa pangsa pasar smartphone Android pada tahun 2020 menurun menjadi 83,8\%, dari 84,1\% pada tahun 2019. Akan tetapi, pangsa pasar iOS meningkat sebesar 6,5\% dari tahun ke tahun (idc.com, 2020). Kemudian, perusahaan riset pasar IDC melaporkan bahwa pada Kuartal ke-4 Tahun 2020, Apple berada pada urutan teratas menggeser Samsung sebagai penguasa pangsa pasar smartphone global (tekno.kompas.com, 2021). Berdasarkan pernyataan tersebut dapat terlihat pangsa pasar Apple yang tetap meningkat walaupun tidak menggunakan ambassador, sedangkan smartphone Android yang rajin menggunakan ambassador mengalami penurunan pangsa pasar. Oleh karena itu, perlu dipertanyakan kebutuhan brand ambassador dalam memunculkan minat beli. Minat beli dapat diperoleh dengan proses belajar dan proses berpikir yang membentuk suatu sudut pandang atau persepsi. Menurut (Pussandha, 2017), minat beli ini menciptakan suatu 
motivasi yang secara terus-menerus terekam dalam benak calon konsumen dan menjadi suatu keinginan yang sangat kuat yang pada akhirnya muncul pada saat konsumen tersebut harus memenuhi apa yang dia butuhkan dengan cara mengaktualisasikan apa yang ada di dalam benaknya tersebut.

Pengaktualisasian tersebut dapat tercermin dalam niat perilaku yang ditunjukkan. Menurut (Mowen dalam Salimun dan Sugiyanto, 2019), efek hierarki minat beli digunakan untuk menggambarkan urutan proses munculnya keyakinan (beliefs), sikap (attitudes) dan perilaku pengetahuan kognitif yang dimiliki konsumen dengan mengaitkan atribut, manfaat dan objek (dengan mengetahui informasi), sementara itu, sikap mengacu pada perasaan atau respon efektifnya. Menurut Oliver dalam (Aptaguna dan Pitaloka, 2016), sikap berlaku sebagai acuan yang mempengaruhi dari lingkungannya. Perilaku adalah segala sesuatu yang dikerjakan oleh konsumen untuk membeli, membuang, dan menggunakan produk dan jasa.

Di dalam penelitian ini, ketiga komponen bergerak dalam formasi standar, yakni kognisi, sikap dan perilaku. Menurut Mowen dalam (Salimun dan Sugiyanto, 2019): munculnya ketiga komponen tersebut tidak lepas dari informasi yang diterima oleh konsumen. Selanjutnya ditentukan pula indikator dari minat beli yang dikembangkan dari penelitian Oliver dalam (Aptaguna dan Pitaloka, 2016) dimana telah disesuaikan dengan penelitian ini yaitu mencari tahu lebih lanjut mengenai produk tersebut, timbul ketertarikan untuk membeli akibat adanya brand ambassador tersebut, mempertimbangkan untuk membeli produk, dan sungguhsungguh ingin membeli produk tersebut.

Royan dalam (Sriyanto dan Kuncoro, 2019) menyatakan bahwa penggunaan brand ambassador dilakukan oleh perusahaan untuk memengaruhi atau mengajak konsumen. Hal ini bertujuan agar konsumen tertarik menggunakan produk, terlebih karena pemilihan brand ambassador biasanya didasarkan pada pencitraan melalui seorang selebrititas yang terkenal. Brand ambassador adalah identitas, dimana mereka bertindak sebagai alat pemasaran yang mewakili pencapaian individualism kejayaan manusia serta komodifikasi dan komersialisasi suatu produk.

Terdapat model Viscap yang dikembangkan oleh Royan dalam (Andini, 2016: 12) dimana indikator dari brand ambassador tersebut adalah: visibility, credibility, attraction, dan power. (Debby, 2018) menyatakan brand ambassador harus menjadi alat pemasaran yang mewakili produk suatu perusahaan dan biasanya berasal dari kalangan artis atau orang populer untuk dapat terhubung ke publik demi menargetkan pangsa pasar dan meningkatkan volume penjualan.

Tugas dari seorang brand ambassador jelas tidak mudah, karena harus bisa merefleksikan brand yang dia bawa dengan baik dan hal tersebut berkaitan juga dengan karakter dari dirinya sendiri. Selebriti atau orang populer sering menjadi pilihan para perusahaan untuk menjadikan mereka sebagai duta merek dari produknya hal ini bukan tanpa sebab, melainkan mereka sudah dikenal banyak orang dan dapat menjadi magnet bagi konsumen yang melihatnya untuk tertarik membeli produk tersebut. Studi dari (Cece, 2015) menyatakan bahwa brand ambassador memiliki pengaruh yang signifikan terhadap minat beli. Hal senada juga disampaikan (Ningrum, 2016) bahwa brand ambassador memiliki pengaruh sebesar $42,9 \%$ terhadap minat beli. Hal tersebut menunjukkan bahwa brand ambassador merupakan salah satu yang dapat menentukan muncul tidaknya minat beli dari konsumen. 
Menurut (Debby, 2018) pada dasarnya, timbulnya keinginan minat beli konsumen didasarkan pada tahu tidaknya konsumen akan produk tersebut dan disitulah peran brand ambassador untuk memperkenalkan suatu produk kepada konsumen sehingga timbul kesadaran di benak konsumen. Menurut Humdiana dalam (Barus, 2015), kesadaran merek adalah kemampuan pelanggan untuk mengenali atau mengingat kembali sebuah merek dan mengaitkannya dengan satu kategori produk tertentu. Kesadaran (awareness) menggambarkan keberadaan merek di dalam pikiran konsumen, yang dapat menjadi penentu dalam beberapa kategori dan biasanya mempunyai peranan kunci dalam ekuitas merek. Menurut Kao\&Lin dalam (Pangestu dan Rachmawati, 2019), brand equity dianggap sebagai satu rangkaian aset dan kewajiban merek yang terkait dengan merek, nama, dan simbolnya, yang menambah atau mengurangi nilai yang diberikan oleh produk atau layanan kepada perusahaan dan/atau kepada pelanggan perusahaan. Studi dari (Fajar, 2016) menyatakan bahwa brand ambassador mempunyai pengaruh terhadap brand awareness. Penelitian lain dari (Baskorohito, 2014) menyatakan bahwa tagline dan brand ambassador memiliki pengaruh terhadap brand awareness sebesar 23,8\%. Konsumen dalam mengidentifikasi suatu brand berbeda-beda tergantung tingkat komunikasi merek atau persepsi pelanggan terhadap merek produk yang ditawarkan. Secara berurutan, Aaker dalam (Priansa, 2017: 255) menggambarkan tingkat kesadaran merek dalam bentuk: unaware of brand, brand recognition, brand recall, dan top of mind.

Menurut Rahayu (2017) brand awareness atau kesadaran merek merupakan salah satu cara untuk mengukur efektivitas pemasaran yang diukur oleh kemampuan pelanggan untuk mengenali dan/ atau mengingat nama, gambar atau tanda-tanda lain yang terkait dengan merek tertentu. Kesadaran akan merek merupakan salah satu hal penting dalam sukses tidaknya produk di pasaran. Brand awareness yang tinggi diduga mampu mempengaruhi perilaku pembelian konsumen sehingga diharapkan mampu meningkatkan volume penjualan, dari sini dapat terlihat bahwa brand awareness memegang peranan yang penting dalam keberlangsungan hidup perusahaaan.

Begitu pentingnya kesadaran merek untuk mendongkrak minat beli konsumen tercermin dalam penelitian yang dilakukan oleh (Shahid et.al, 2017) menyatakan bahwa konsumen akan cenderung membeli sebuah merek jika mereka sudah mengetahui merek tersebut, disinilah perlu adanya usaha dari perusahaan untuk mengenalkan merek tersebut agar konsumen sadar akan keberadaan merek tersebut. Hal yang senada juga turut disampaikan oleh (Yanti dan Sukotjo, 2016), (Ishak dkk, 2019) yang menyatakan bahwa "Perusahaan dapat membangun merek yang kuat dipikiran pelanggan dengan strategi yang kuat, maka perusahaan tersebut akan memiliki nilai tambah kepada pelanggan yang disebutkan sebagai kesadaran merek. Keputusan pembelian pada wanita muslim generasi milenial salah satunya dipengaruhi oleh kesadaran merek".

Konsumen yang mengetahui dan menyadari akan sebuah merek akan membuat kerja dari perusahaan akan semakin mudah. Di dalam penelitian (Hutter dkk, 2013) menyebutkan bahwa niat beli ditentukan secara positif dan signifikan oleh kesadaran merek. Hal tersebut semakin menegaskan bahwa brand awareness berperan dalam terbentuknya minat beli konsumen. Tidak terkecuali tingginya minat beli smartphone dengan brand Vivo di Kota Tasikmalaya di hampir semua gerai atau toko handphone, merek Vivo selalu menjadi pilihan yang dipandang sebagai merek handphone yang merakyat namun memiliki kualitas premium. Berdasarkan beberapa sampel penelitian pada tahun 2020 Vivo mengalami peningkatan pangsa pasar yang signifikan bahkan saat kondisi Pandemic Covid-19 mampu mengalahkan beberapa pesaing smartphone berbasis android lainnya yang justru mengalami penurunan. Tingginya 
minat beli terhadap smartphone ini belum diketahui secara pasti apakah dipengaruhi oleh brand ambassador dan juga kesadaran akan merek Vivo? Berdasarkan uraian di atas, maka peneliti melakukan penelitian yang ditujukan untuk mengetahui dan menganalisis brand ambassador, brand awareness dan minat beli pada pengguna smartphone Vivo di kota Tasikmalaya.

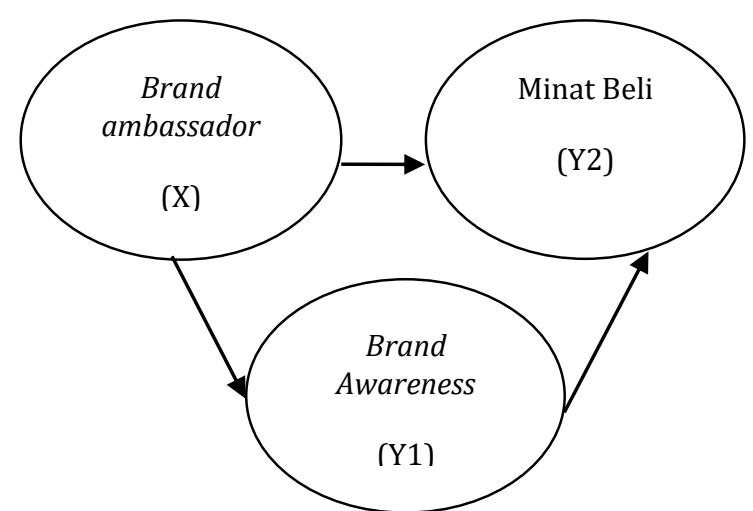

Gambar 1. Kerangka Konseptual Penelitian

Sumber: Data diolah, 2021

\section{Identifikasi Masalah}

Berdasarkan hasil observasi yang telah dilakukan, terdapat beberapa faktor yang berpotensi menjadi permasalahan diantaranya belum teroptimalkannya peran brand ambassador untuk meningkatkan minat beli, belum tahu seberapa besar peran brand ambassador untuk memunculkan brand awareness.

\section{Rumusan Masalah}

Berdasarkan uraian latar belakang, maka rumusan masalah di dalam penelitian ini adalah seberapa besar peran brand ambassador terhadap minat beli melalui brand awareness.

\section{LANDASAN TEORI}

Minat beli dapat diperoleh dengan proses belajar dan proses berpikir yang membentuk suatu sudut pandang atau persepsi. Minat beli ini menciptakan suatu motivasi yang secara terus-menerus terekam dalam benak calon konsumen dan menjadi suatu keinginan yang sangat kuat yang pada akhirnya muncul pada saat konsumen tersebut harus memenuhi apa yang dia butuhkan dengan cara mengaktualisasikan apa yang ada di dalam benaknya tersebut (Bambang, 2010).

Pengaktualisasian tersebut dapat tercermin dalam niat perilaku yang ditunjukkan. Menurut Mowen dalam (Salimun dan Sugiyanto, 2019), efek hierarki minat beli digunakan untuk menggambarkan urutan proses munculnya keyakinan (beliefs), sikap (attitudes) dan perilaku pengetahuan kognitif yang dimiliki konsumen dengan mengaitkan atribut, manfaat dan objek (dengan mengetahui informasi), sementara itu, sikap mengacu pada perasaan atau respon efektifnya. Menurut Oliver dalam (Aptaguna dan Pitaloka, 2016), sikap berlaku sebagai acuan yang mempengaruhi dari lingkungannya. Perilaku adalah segala sesuatu yang dikerjakan oleh konsumen untuk membeli, membuang, dan menggunakan produk dan jasa. 
Di dalam penelitian ini, ketiga komponen bergerak dalam formasi standar, yakni kognisi, sikap dan perilaku. Munculnya ketiga komponen tersebut tidak lepas dari informasi yang diterima oleh konsumen (Mowen dalam Salimun dan Sugiyanto, 2019). Selanjutnya ditentukan pula indikator dari minat beli yang dikembangkan dari penelitian Oliver dalam (Aptaguna dan Pitaloka 2016) dimana telah disesuaikan dengan penelitian ini yaitu mencari tahu lebih lanjut mengenai produk tersebut, timbul ketertarikan untuk membeli akibat adanya brand ambassador tersebut, mempertimbangkan untuk membeli produk, dan sungguh-sungguh ingin membeli produk tersebut.

(Yanti dan Sukotjo, 2016) menyatakan bahwa, perusahaan dapat membangun merek yang kuat dipikiran pelanggan dengan strategi yang kuat, maka perusahaan tersebut akan memiliki nilai tambah kepada pelanggan yang disebutkan sebagai kesadaran merek. Menurut (Doucett dalam Nisa, 2019), brand ambassador merupakan seseorang yang memiliki passion terhadap brand, mau memperkenalkannya dan bahkan dengan sukarela memberikan informasi mengenai brand.

Terdapat model Viscap yang dikembangkan oleh Royan dalam (Andini, 2016) dimana indikator dari brand ambassador tersebut adalah: visibility, credibility, attraction, dan power. Menurut (Debby, 2018), brand ambassador harus menjadi alat pemasaran yang mewakili produk suatu perusahaan dan biasanya berasal dari kalangan artis atau orang populer untuk dapat terhubung ke publik demi menargetkan pangsa pasar dan meningkatkan volume penjualan.

Tugas dari seorang brand ambassador jelas tidak mudah, karena harus bisa merefleksikan brand yang dia bawa dengan baik dan hal tersebut berkaitan juga dengan karakter dari dirinya sendiri. Selebriti atau orang populer sering menjadi pilihan para perusahaan untuk menjadikan mereka sebagai duta merek dari produknya hal ini bukan tanpa sebab, melainkan mereka sudah dikenal banyak orang dan dapat menjadi magnet bagi konsumen yang melihatnya untuk tertarik membeli produk tersebut. Studi dari (Cece, 2015) menyatakan bahwa brand ambassador memiliki pengaruh yang signifikan terhadap minat beli. Hal senada juga disampaikan (Ningrum, 2016) bahwa brand ambassador memiliki pengaruh sebesar $42,9 \%$ terhadap minat beli. Hal tersebut menunjukkan bahwa brand ambassador merupakan salah satu yang dapat menentukan muncul tidaknya minat beli dari konsumen. (Bahrunsyah, 2018), (Meatry dkk, 2018) juga membuktikan bahwa brand awareness berpengaruh terhadap minat beli.

Pada dasarnya, timbulnya keinginan minat beli konsumen didasarkan pada tahu tidaknya konsumen akan produk tersebut dan disitulah peran brand ambassador untuk memperkenalkan suatu produk kepada konsumen sehingga timbullah kesadaran di benak konsumen (Debby, 2018). Menurut Humdiana dalam (Barus, 2015), kesadaran merek adalah kemampuan pelanggan untuk mengenali atau mengingat kembali sebuah merek dan mengaitkannya dengan satu kategori produk tertentu. Kesadaran (awareness) menggambarkan keberadaan merek di dalam pikiran konsumen, yang dapat menjadi penentu dalam beberapa kategori dan biasanya mempunyai peranan kunci dalam brand equity. Studi dari (Fajar, 2016) menyatakan bahwa brand ambassador mempunyai pengaruh terhadap brand awareness. Penelitian lain dari (Baskorohito, 2014) menyatakan bahwa tagline dan brand ambassador memiliki pengaruh terhadap brand awareness sebesar 23,8\%. Konsumen dalam mengidentifikasi suatu brand berbeda-beda tergantung tingkat komunikasi merek atau persepsi pelanggan terhadap merek produk yang ditawarkan. Secara berurutan, Aaker dalam (Priansa 
2017) menggambarkan tingkat kesadaran merek dalam bentuk: unaware of brand, brand recognition, brand recall, dan top of mind.

Menurut (Rahayu, 2017), brand awareness atau kesadaran merek merupakan salah satu cara untuk mengukur efektivitas pemasaran yang diukur oleh kemampuan pelanggan untuk mengenali dan/ atau mengingat nama, gambar atau tanda-tanda lain yang terkait dengan merek tertentu. Kesadaran akan merek merupakan salah satu hal penting dalam sukses tidaknya produk di pasaran. Brand awareness yang tinggi diduga mampu mempengaruhi perilaku pembelian konsumen sehingga diharapkan mampu meningkatkan volume penjualan, dari sini dapat terlihat bahwa brand awareness memegang peranan yang penting dalam keberlangsungan hidup perusahaaan.

Begitu pentingnya kesadaran merek untuk mendongkrak minat beli konsumen tercermin dalam penelitian yang dilakukan oleh (Shahid dkk, 2017) menyatakan bahwa konsumen akan cenderung membeli sebuah merek jika mereka sudah mengetahui merek tersebut, disinilah perlu adanya usaha dari perusahaan untuk mengenalkan merek tersebut agar konsumen sadar akan keberadaan merek tersebut. Hal yang senada juga turut disampaikan oleh (Yanti dan Sukotjo, 2016), (Ishak dkk, 2019) yang menyatakan bahwa, perusahaan dapat membangun merek yang kuat dipikiran pelanggan dengan strategi yang kuat, maka perusahaan tersebut akan memiliki nilai tambah kepada pelanggan yang disebutkan sebagai kesadaran merek. Keputusan pembelian pada wanita muslim generasi milenial salah satunya dipengaruhi oleh kesadaran merek. Di dalam penelitian (Yuliati dan Maulidi, 2017) dan (Gunawan, 2014) menyebutkan bahwa niat beli ditentukan secara positif dan signifikan oleh kesadaran merek. Hal tersebut semakin menegaskan bahwa brand awareness berperan dalam terbentuknya minat beli konsumen.

\section{METODE PENELITIAN}

Penelitian ini akan menguji pengaruh brand ambassador terhadap minat beli melalui brand awareness pada pengguna smartphone android di kota Tasikmalaya. Penelitian ini menggunakan pendekatan kuantitatif dan metode yang digunakan adalah metode survey. Alat Analisis yang digunakan untuk menguji pengaruh tersebut adalah Analisis Structural Equation Modelling (SEM).

Populasi dalam penelitian ini termasuk dalam populasi tak terbatas (infinite), karena kumpulan objek atau individu yang menjadi objek penelitian tidak diketahui batas wilayahnya atau jumlah keseluruhan individu yang terdapat di wilayah populasi tidak diketahui secara tepat atau secara pasti. Dalam penelitian ini, penentuan ukuran sampel didasarkan pada pendapat (Hair, 2014: 444) yaitu untuk penelitian survey ukuran minimal sampel adalah 100 orang responden. Menurut (Sugiyono, 2018), teknik sampel yang digunakan adalah purposive sampling dimana penarikan sampel didasarkan pada pertimbangan tertentu/ pribadi peneliti yang bersangkutan. Adapun pertimbangan sampel yang digunakan dalam penelitian ini adalah pengguna smartphone Android yang baru melakukan pembelian kurang dari 1 tahun. Berdasarkan grand theory dan beberapa penelitian terdahulu dihasilkan hipotesis 1: terdapat pengaruh dari brand ambassador terhadap minat beli. Hipotesis 2: terdapat pengaruh dari brand ambassador terhadap brand awareness. Hipotesis 3: terdapat pengaruh dari brand awareness terhadap minat beli. 


\section{HASIL DAN PEMBAHASAN}

Data yang telah diperoleh adalah sebanyak 110 pengguna smartphone Android yang baru melakukan pembelian kurang dari 1 tahun. Deskripsi identitas responden dalam penelitian ini dapat dikelompokkan menjadi beberapa kelompok yaitu berdasarkan usia, pendapatan, jenis kelamin, dan pekerjaan.

Tabel 1. Karakterisik Responden

\begin{tabular}{|l|l|c|c|}
\hline \multicolumn{2}{|c|}{ Karakteristik } & Jumlah & Frekuensi \\
\hline \multirow{4}{*}{ Usia } & $18-23$ Tahun & 62 & $56.07 \%$ \\
\cline { 2 - 4 } & $24-29$ Tahun & 21 & $19.31 \%$ \\
\cline { 2 - 4 } & $30-35$ Tahun & 15 & $14.02 \%$ \\
\cline { 2 - 4 } & $>35$ Tahun & 12 & $10.59 \%$ \\
\hline \multirow{4}{*}{ Pendapatan } & $<3.000 .000$ & 66 & $59.81 \%$ \\
\cline { 2 - 4 } & $3.000 .001-5.000 .000$ & 24 & $22.12 \%$ \\
\cline { 2 - 4 } & $5.000 .001-7.000 .000$ & 10 & $9.03 \%$ \\
\cline { 2 - 4 } & $>7.000 .000$ & 10 & $9.03 \%$ \\
\hline \multirow{3}{*}{ Jenis Kelamin } & Laki-laki & 48 & $43.30 \%$ \\
\cline { 2 - 4 } & Wanita & 62 & $56.70 \%$ \\
\hline & Mahasiswa & 48 & $43.30 \%$ \\
\cline { 2 - 4 } & PNS & 12 & $11.21 \%$ \\
\cline { 2 - 4 } & Wiraswasta & 23 & $21.18 \%$ \\
\cline { 2 - 4 } & Karyawan Swasta & 27 & $24.30 \%$ \\
\hline
\end{tabular}

Sumber: Hasil perhitungan data kuesioner, 2021.

Hasil pengumpulan data karakteristik responden berdasarkan usia dalam penelitian ini secara kuantitatif, dapat dilihat pada Tabel 1, bahwa pengguna smartphone Android di kota Tasikmalaya paling banyak berusia 18 hingga 23 tahun yaitu mencapai 56,07\% dari total keseluruhan responden yang terpilih. Profil responden berdasarkan pendapatan pengguna smartphone Vivo di kota Tasikmalaya, secara kuantitatif paling banyak memiliki pendapatan dibawah Rp. 3.000.000, yaitu mencapai 59,81\% dari total keseluruhan responden yang terpilih. Sedangkan, berdasarkan jenis kelamin, secara kuantitatif dapat dilihat bahwa pengguna smartphone Vivo di kota Tasikmalaya sebagian besar wanita yaitu mencapai 56,70\% dari total keseluruhan responden yang terpilih. Pekerjaan pengguna smartphone Vivo di kota Tasikmalaya paling banyak sebagai mahasiswa, yaitu mencapai 43,30\% dari total keseluruhan responden yang terpilih.

Untuk mengetahui pengaruh brand ambassador (X) terhadap brand awareness (Y1) dan minat beli (Y2) digunakan Structural Equation Modeling (SEM). Berdasarkan hasil analisis SEM dengan menggunakan software AMOS 4.0, hasil uji normalitas dengan menggunakan kriteria CR sebesar $\pm 2,58$ pada tingkat signifikansi 0,01 dengan nilai terbesar 2,123 sehingga dapat dikatakan data yang digunakan dalam penelitian ini berdistribusi normal. Selanjutnya, hasil evaluasi outlier univariat dengan nilai Zscore terbesar sebesar -2,88 dan 1,66 yang nilainya masih diantara \pm 3 . Sedangkan untuk outlier multivariat, nilai mahalanobis terbesar yaitu 31,299 yang mana besarannya masih lebih kecil dari nilai tabel chi-kuadrat 
$(128,803)$. Dengan demikian, data yang digunakan dalam penelitian ini bebas dari univariate dan multivariate outliers.

Dengan kriteria suatu indikator dikatakan valid adalah ketika loading factor $\geq 0,40$, berdasarkan hasil analisis, nilai loading factor yang terkecil yaitu 0,837 sehingga dapat dikatakan valid. Hasil perhitungan reliabilitas dapat dilihat dari construct reliability dan variabel extracted. Untuk besaran construct reliability dari variabel brand ambassador, brand awareness dan minat beli $>0,70$, sedangkan nilai variance extracted ketiga variabel tersebut adalah $>0,50$. Oleh karena itu dapat dikatakan bahwa indikator yang digunakan dapat mewakili variabel penelitian.

Secara keseluruhan, uji kesesuaian model ditunjukkan pada tabel berikut:

Tabel 2. Goodness of Fit Index

\begin{tabular}{|l|l|l|l|}
\hline Goodness of Fit Index & Hasil Analisis & Cut-off Value & Evaluasi Model \\
\hline RMSEA & 0,066 & $\leq 0,08$ & Baik \\
\hline GFI & 0,901 & $\geq 0,90$ & Baik \\
\hline CMIN/DF & 1,481 & $\leq 2,00$ & Baik \\
\hline TLI & 0,979 & $\geq 0,95$ & Baik \\
\hline CFI & 0,983 & $\geq 0,95$ & Baik \\
\hline
\end{tabular}

Sumber: Output AMOS 4.0 (data diolah, 2021)

Kesesuaian model dapat dilihat dari RMSEA, GFI, CMN/DF, TLI dan CFI. Berdasarkan hasil analisis nilai RMSEA $(0,066) \leq 0,08$, GFI $(0,901) \geq 0,90$, CMIN/DF $(1,481)$ $\leq 2,00$, TLI $(0,979) \geq 0,95$, dan CF $(0,983) \geq 0,95$. Karena nilai tersebut sudah melebihi dari cut off value, maka dapat dikatakan model dalam penelitian ini sudah baik.

Dengan taraf signifikansi 5\% $(0,05)$ dan nilai cut-off 1,96 , tabel berikut menyajikan nilai koefisien regresi dan C.R (Critical Ratio) sebagai dasar penerimaan hipotesis penelitian. Hasil analisis dalam penelitian ini dapat dilihat pada tabel berikut:

Tabel 2. Standardized Regression Weight for Hypothesis Testing

\begin{tabular}{|c|c|c|c|c|c|}
\hline & & & C.R. & $\mathrm{P}$ & Kesimpulan \\
\hline$\overline{\text { BAw }}$ & $<---$ & BAm & 5,639 & ,000 & Signifikan \\
\hline PI & $<---$ & BAm & 2,017 & ,044 & Signifikan \\
\hline PI & $<---$ & BAw & 7,857 & ,000 & Signifikan \\
\hline
\end{tabular}

Sumber: Output AMOS 4.0 (data diolah, 2021)

Hipotesis 1 menyatakan bahwa terdapat pengaruh dari brand ambassador terhadap minat beli. Dengan menggunakan AMOS 4.0, diperoleh hasil CR sebesar 2,017 dan $p$-value sebesar 0,044. Sehingga brand ambassador berpengaruh terhadap minat beli konsumen. Hal tersebut menunjukkan bahwa semakin bagus brand ambassador maka semakin tinggi minat beli konsumen. 
Hipotesis 2 menyatakan bahwa terdapat pengaruh dari brand ambassador terhadap brand awareness. Dengan menggunakan AMOS 4.0, diperoleh hasil CR sebesar 5,639 dan $p$ value sebesar 0,000. Oleh karena itu, brand ambassador berpengaruh terhadap brand awareness. Hal tersebut menunjukkan bahwa semakin bagus brand ambassador maka semakin besar brand awareness konsumen.

Hipotesis 3 menyatakan bahwa terdapat pengaruh dari brand awareness terhadap minat beli. Dengan menggunakan AMOS 4.0, diperoleh hasil CR sebesar 7,857 dan p-value sebesar 0,000. Oleh karena itu, brand awareness berpengaruh terhadap minat beli konsumen. Hal tersebut menunjukkan bahwa semakin besar brand awareness maka semakin tinggi minat beli konsumen.

\section{KESIMPULAN DAN SARAN}

\section{Kesimpulan}

Minat beli di smartphone Android ternyata masih memerlukan peran dari brand ambassador. Walaupun tidak meningkatkan pangsa pasar, untuk saat ini, strategi brand ambassador masih bisa digunakan untuk mempertahankan pangsa pasar smartphone Android. Strategi brand ambassador juga memiliki peran sebagai penguatan identitas dari setiap merek smartphone android, mengingat tingginya persaingan di industri smartphone android ini. Selain itu, strategi brand ambassador dapat digunakan untuk meningkatkan awareness konsumen smartphone android dimana tingkat awareness yang tinggi dapat mempengaruhi minat pembelian dari konsumen smartphone android. Oleh karena itu, semakin baik strategi brand ambassador yang meliputi visibility, credibility, attraction, dan power akan meningkatkan awarenees yang berdampak pada peningkatan minat beli konsumen smartphone android di tasikmalaya.

\section{Saran}

Penelitian selanjutnya dapat memasukkan variabel brand identity atau brand image sebagai variabel yang memediasi brand ambassador terhadap minat beli konsumen. Selain itu, brand ambassador bisa dispesifikkan menjadi celebrity endorser, mengingat ambassador yang digunakan oleh beberapa perusahaan smartphone bukan publik figur atau selebriti. Penelitian ini juga memiliki keterbatasan dari cakupan wilayah yang terfokus pada kota Tasikmalaya, sehingga penelitian selanjutnya yang serupa dapat meperluas cakupan wilayah penelitian agar mendapatkan hasil yang lebih baik.

\section{DAFTAR PUSTAKA}

Aptaguna dan Pitaloka. (2016). Pengaruh Kualitas Layanan Dan Harga Terhadap Minat Beli Jasa Go-Jek. Widyakala Journal, Vol. 3, 2016. P49-56.

Barata, A.A. (2006). Dasar-dasar Pelayanan Prima: Persiapan Membangun Budaya Pelayanan Prima Untuk Meningkatkan Kepuasan dan Loyalitas Pelanggan. Jakarta: PT. Elex Media Komputindo. 
Barus, Harry Christian. (2015). Pengaruh Ekuitas Merek (Brand Equity) Terhadap Keputusan pembelian Smartphone Blackberry. Jurnal Ilmu Administrasi Bisnis. vol. 4, no. 1, pp. 328-334.

Gunawan (2014). Analisis Pengaruh Iklan Televisi dan Endorser Terhadap Purchase Intention Dengan Brand Awareness Sebagai Variabel Intervening. Jurnal Strategi Pemasaran Vol 2, No 1.

Hair, J.F., et al. (2014). Multivariate Data Analysis, $7^{\text {th }}$ Edition, New Jersey, Prentice-Hall.

IDC. (2021, 8 April). Smartphone Market Share. Diakses pada 10 April 2021, dari https://www.idc.com/promo/smartphone-market-share.

Ishak, Suraiya, dkk. (2019). Cosmetics purchase behavior of educated millennial Muslim females. Journal of Islamic Marketing: Volume 11 Issue 5.

Janasz C. De. Suzanne, Dowd, Schneider. (2015). Interpersonal Skills in Organizations Fifth Edition. New York: Mc Graw Hill International Edition.

Kompas.com. (2021, 18 Maret). Pasar Smartphone Indonesia Ternyata Naik di Tengah Pandemi. Diakses pada 10 April 2021, dari https://tekno.kompas.com/read/2021/03/18/09060077/pasar-smartphone-indonesiaternyata-naik-di-tengah-pandemi?page=all

M. Kurniasari, and A. Budiatmo, Pengaruh Social Media Marketing, Brand Awareness Terhadap Keputusan Pembelian dengan Minat Beli Sebagai Variabel Intervening Pada J.Co Donuts \& Coffee Semarang," Jurnal Ilmu Administrasi Bisnis, vol. 7, no. 3, pp. 152-159, Jul. 2018. [Online].

Nisa, Nuriena and S. Widowati Herieningsih. (2019). Hubungan Terpaan Iklan dan Kredibilitas Brand Ambassador Dengan Minat Beli Produk Vivo Smartphone. Interaksi Online, vol. 8, no. 1, pp. 26-37, Dec. 2019.

Pangestu, Putra Akbar dan Indira Rachmawati (2019). Perceived E-Service Qualitydan Brand EquityProduk Tcash. Jurnal Manajemen dan Bisnis: Performa Vol.16, No. 2 September 2019. DOI: https://doi.org/10.29313/performa.v16i2.3634.

Pussandha, Fitri Eko (2017). Pengaruh Sikap, Motivasi dan Brand Image Terhadap Minat Konsumen Berkunjung Ke Tempat Karaoke Happy Puppy Jogjakarta (Survei pada Mahasiswa yang berdomisili di Kota Jogjakarta)". Tesis Universitas Muhammadiyah Purworejo.

Rahayu, Riris Mey. (2017). Membangun Brand Awareness Pada Usaha Mikro Kecil Dan Menengah. Journal of Management Studies. Vol 11, No 2 (2017). DOI: https://doi.org/10.21107/kompetensi.v11i2.3534.

Salimun dan Sugiyanto. (2019). Pengaruh Brand Image dan Kualitas Pelayanan terhadap Minat Beli Konsumen pada Rumah Makan Begal (Bebek Galak). Prosiding Seminar Nasional Humanis 2019.

Sriyanto, Agus dan Aris Wahyu Kuncoro. (2019). Pengaruh Brand Ambassador, Minat Beli, Dan Testimoni Terhadap Keputusan Pembelian (Studi Pada Situs Jual Beli Online Shop 
Shopee Indonesia di Universitas Budi Luhur Periode Februari -April 2018). Jurnal Ekonomika dan Manajemen Vol. 8 No. 1 April 2019 hlm. 21-34.

Sugiyono. (2018). Metode Penelitian Kuantitatif. Bandung: Alfabeta.

Sukirman. (2020). Strategi Keunggulan Bersaing Melalui Keunggulan Asosiasi Merk, Kekuatan Asosiasi Merk dan Keunikan Asosiasi Merk. Jurnal Manajemen dan Bisnis (Performa). Vol.17 No.1 DOI: https://doi.org/10.29313/performa.v17i1.4872

Yanti, Mery Oky Zufi dan Hendri Sukotjo. (2016). Pengaruh Kesadaran Merek, Asosiasi Merek, dan Brand Image Terhadap Keputusan Pembelian Aqua. Jurnal Ilmu dan Riset Manajemen : Volume 5, Nomor 5.

Yuliati, Ai Lili dan Refi Agus Maulidi (2017). Pengaruh Tingkat Brand Awareness terhadap Minat Beli Apple iPhone. Vol. 1 No. 1 (2017): ISEI Business \& Management Review 